\title{
Impact of siRNA targeting of $\beta$-catenin on differentiation of rat neural stem cells and gene expression of Ngn1 and BMP4 following in vitro hypoxic-ischemic brain damage
}

\author{
XIAOYING ZHANG, CUICUI ZHU, QIONG LUO, JV DONG, LV LIU, MIN LI, \\ HONGTAO ZHU, XIANGPING MA and JUN WANG
}

Department of Pediatrics, The First Affiliated Hospital of Xinjiang Medical University, Ürümqi, Xinjiang 830054, P.R. China

Received June 7, 2015; Accepted April 14, 2016

DOI: $10.3892 / \mathrm{mmr} .2016 .5667$

\begin{abstract}
The aim of the present study was to investigate the possible damage-repair mechanisms of neural stem cells (NSCs) following hypoxic-ischemic brain damage (HIBD). NSCs obtained from Sprague Dawley rats were treated with tissue homogenate from normal or HIBD tissue, and $\beta$-catenin expression was silenced using siRNA. The differentiation of NSCs was observed by immunofluorescence, and semiquantitative reverse transcription-polymerase chain reaction and western blot analysis were applied to detect the mRNA and protein expression levels of Ngn1 and BMP4 in the NSCs. Compared with control NSCs, culture with brain tissue homogenate significantly increased the differentiation of NSCs into neurons and oligodendrocytes $(\mathrm{P}<0.05)$, whereas differentiation into astrocytes was significantly reduced $(\mathrm{P}<0.05)$. Compared with negative control-transfected cells, knockdown of $\beta$-catenin expression significantly decreased the differentiation of NSCs into neurons and oligodendrocytes $(\mathrm{P}<0.01)$, whereas the percentage of NSCs differentiated into astrocytes was significantly increased $(\mathrm{P}<0.01)$. Compared with control NSCs, the mRNA and protein expression levels of Ngn1 were significantly increased $(\mathrm{P}<0.01)$ and BMP4 levels were significantly reduced $(\mathrm{P}<0.01)$ by exposure of the cells to brain tissue homogenate. Compared with the negative control plasmid-transfected NSCs, the levels of Ngn1 mRNA and protein were significantly reduced by $\beta$-catenin siRNA $(\mathrm{P}<0.01)$, whereas BMP4 levels were significantly increased $(\mathrm{P}<0.01)$. In summary, the damaged brain tissues in HIBD may promote NSCs to differentiate into neurons for self-repair processes. $\beta$-Catenin, BMP4 and Ngn1 may be important
\end{abstract}

Correspondence to: Professor Xiaoying Zhang, Department of Pediatrics, The First Affiliated Hospital of Xinjiang Medical University, 1 Li-Yu-Shan-Road, Ürümqi, Xinjiang 830054, P.R. China

E-mail: xiaoyingzhangcn@163.com

Key words: $\beta$-catenin, RNA interference, hypoxic-ischemic brain damage, electroporation transfection for the coordination of NSC proliferation and differentiation following HIBD.

\section{Introduction}

Hypoxic-ischemic encephalopathy (HIE) is a common cause of brain damage in neonates, and is the leading cause of severe neurological sequelae in children (1). Of the 130 million births worldwide each year, four million infants will suffer from birth asphyxia, and of these, one million will result in mortality and a similar number will develop serious and long-term sequelae, including neurodevelopmental disorders (2). In China, the incidence rate of neonatal asphyxia is $1.14-11.7 \%$, and the incidence of HIE in full-term live birth infants is 1-2/1000 affected newborns. Approximately 15-20\% of affected newborns will succumb to the condition within the neonatal period, and an additional $25-30 \%$ will develop severe and permanent neurological handicaps (3), including cerebral palsy, seizures, visual defects, mental retardation, cognitive impairment and epilepsy (4). There is currently no specific treatment for HIE. Previous studies have demonstrated that endogenous neural stem cells (NSCs) exist in certain areas of the brain, and that brain damage may stimulate the proliferation, differentiation and self-repair mechanisms of these NSCs (5-7). However, endogenous stem cells are limited in number, and their survival may be affected by neurite growth inhibitory factors and deficiencies of neurotrophic factors. Thus, the potential for spontaneous brain repair is limited. When brain damage occurs, the mechanisms of NSC proliferation and differentiation may provide a method to enhance the autogenous repair functions of the brain, thus, providing novel insight and treatment strategies for hypoxic-ischemic brain damage (HIBD). $\beta$-Catenin is a crucial molecule in the Wnt signaling pathway. During ischemic brain injuries, $\beta$-catenin is important for the regulation of NSC proliferation and differentiation (8-10). Neurogenin 1 (Ngn1) is a downstream target gene of $\beta$-catenin, and previous studies have demonstrated that Ngn1 is important during the differentiation of NSCs into neurons $(11,12)$. As a member of the bone morphogenetic protein (BMP) family, the synergy between BMP4 and $\beta$-catenin is important in determining the differentiation pathway of NSCs $(13,14)$. The regulatory role of 
the Wnt $/ \beta$-catenin signaling system during HIBD remains unclear. Therefore, referring to the literature (15), the present study cultured NSCs in brain tissue homogenate from normal and HIBD brains to simulate the respective microenvironments. Additionally, NSCs were transfected with $\beta$-catenin small interfering RNA (siRNA) to investigate the effects of $\beta$-catenin on NSC differentiation, and the gene expression levels of Ngn1 and BMP4. The current study aimed to investigate the potential mechanisms of NSC differentiation in HIBD rats at the in vitro cell level.

\section{Materials and methods}

Isolation, sampling and culture of NSCs from cerebral cortex of neonatal Sprague Dawley (SD) rats. A mix of male and female $\mathrm{SD}$ rats ( $\mathrm{n}=50$; age, $1-3$ days; weight, $10.5 \pm 1.1 \mathrm{~g}$ ) were provided by The Experimental Animal Center of The First Affiliated Hospital of Xinjiang Medical University (Ürümqi, China). They were sacrificed by abdominal injection of $100 \mathrm{~g} / \mathrm{l}$ chloral hydrate (Sigma-Aldrich, St. Louis, MO, USA), then disinfected by soaking in $750 \mathrm{ml} / \mathrm{l}$ ethanol for $5 \mathrm{~min}$. The cerebral cortex tissues were isolated and digested in trypsin (Sigma-Aldrich) at $37^{\circ} \mathrm{C}$ for $15 \mathrm{~min}$. Digested tissue was filtered through a 200-mesh filter (Fuzhou Maixin Biotechnology Development Co., Ltd., Fuzhou, China), then centrifuged at $157 \mathrm{x} g$ for $5 \mathrm{~min}$, the supernatant was discarded and cells were resuspended in Dulbecco's modified Eagle's medium (DMEM)/F12 (Hyclone; GE Healthcare Life Sciences, Logan, UT, USA), containing $20 \mathrm{ml} / 1 \mathrm{~B} 27,10 \mathrm{mg} / \mathrm{l}$ basic fibroblast growth factor and $20 \mathrm{mg} / 1$ epidermal growth factor, all purchased from Gibco (Thermo Fisher Scientific, Inc., Waltham, MA, USA). Cells were seeded into culture flasks and cultured at $37^{\circ} \mathrm{C}$ and in an atmosphere of $50 \mathrm{ml} / \mathrm{C} \mathrm{CO}_{2}$. Half the medium was changed every 3-4 days, and the cells were passaged once every 7 days. The present study was approved by the ethics committee of The First Affiliated Hospital of Xinjiang Medical University.

Cell transfection. Cells were harvested and centrifuged at $4^{\circ} \mathrm{C}, 640 \mathrm{x} \mathrm{g}$ for $5 \mathrm{~min}$, then resuspended in DMEM/F12 at room temperature at a density of $2.5 \times 10^{9}-2.5 \times 10^{10}$ cells $/ 1$. Electroporation apparatus (Multiporator 4308 electroporation system) was purchased from Eppendorf (Hamburg, Germany). The cell suspension was transferred into electrotransformation cuvettes, and $20 \mu \mathrm{g}$ plasmid (pGCPU6/GFP/Neo siRNA expression vector; Shanghai Ji Kai Gene Chemical Technology Co., Ltd., Shanghai, China) was added, while an equal volume of electrotransformation solution was added to the blank control group. Electroporation was performed at $300 \mathrm{~V}$ for $60 \mu \mathrm{sec}$. The cells were transferred into culture flasks 5-10 min later and cultured at $37^{\circ} \mathrm{C}$ and in a $5 \mathrm{ml} / 1 \mathrm{CO}_{2}$ atmosphere.

Preparation of HIBD model and brain tissue homogenate. Healthy male and female, SD rats $(n=50$; age, 7 days; weight, $13.2 \pm 1.4 \mathrm{~g}$ ) obtained from the Experimental Animal Center of The First Affiliated Hospital of Xinjiang Medical University were randomly divided into control and HIBD groups. The control group $(n=50)$ received no treatment. In the HIBD group $(n=100)$, the Rice-Vannucci method (16) was used to perform the HIBD model. The rats were anesthetized by ether inhalation $(1.5 \mathrm{ml}$; Sigma-Aldrich) and the skin was disinfected with $750 \mathrm{ml} / \mathrm{l}$ alcohol. Incision to the neck separated the left common carotid artery and was ligatured with 7.0 sterilized silk wire (Shanghai Nation Medical Equipment Co., Ltd., Shanghai, China), the vessel was cut at the middle of ligation. Following $2 \mathrm{~h}$ rest, the rat was placed into a plexiglass hypoxic chamber $(30 \times 40 \times 50 \mathrm{~cm})$ at normal atmospheric pressure. Nitrogen-oxygen mixture entered the chamber through a 1x1-cm hole on one side. A hole at the other side was connected to a CY-12C portable digital oxygen analyzer (Meicheng Electrochemical Analytical Instruments, Hangzhou, China). The bottom of the chamber was covered with soda lime to absorb $\mathrm{CO}_{2}$ and moisture. The oxygen concentration inside the cabin was controlled at $\sim 8 \mathrm{ml} / 1$, the temperature at $36 \pm 1^{\circ} \mathrm{C}$, and humidity was $70 \pm 5 \mathrm{ml} / 1$. The rats were under hypoxic conditions for a $2 \mathrm{~h}$ period. After $24 \mathrm{~h}$, the HIBD rats and the control SD rats were sacrificed with $100 \mathrm{~g} / \mathrm{l}$ chloral hydrate by abdominal injection, and the whole left brain tissues were removed and suspended in DMEM/F12 (9X volume of brain tissue). The tissues were homogenized on ice and centrifuged at $3,913 \mathrm{x} \mathrm{g}$ at $4^{\circ} \mathrm{C}$ for $15 \mathrm{~min}$. The supernatant was collected, divided into $1.5 \mathrm{ml}$ centrifuge tubes and stored at $-80^{\circ} \mathrm{C}$.

Co-culture of brain tissue supernatant and NSCs. NSCs were collected $24 \mathrm{~h}$ after transfection and centrifuged at $157 \mathrm{x} \mathrm{g}$ for $5 \mathrm{~min}$. The supernatant was discarded and the precipitate was resuspended in DMEM/F12. The clusters of cells were pipetted into single cells by syringe needle, then seeded into 6 -well plates. The brain tissue homogenate supernatants of normal and HIBD rats were added to the cells, according to the different experimental groupings, at an equal ratio of homogenate to medium.

Experimental grouping. The second and third generation NSCs were randomly divided into 5 groups as follows: i) Blank control group without plasmid transfection (CON group); ii) NSCs transfected with negative control (NC) plasmid for $24 \mathrm{~h}$, co-cultured with normal brain tissue homogenate ( $\mathrm{NC}+\mathrm{N}$ group); iii) NSCs transfected with NC plasmid for $24 \mathrm{~h}$, co-cultured with HIBD brain tissue homogenate (NC+HIBD group); iv) NSCs transfected with $\beta$-catenin siRNA (Shanghai Ji Kai Gene Chemical Technology Co., Ltd.) for $24 \mathrm{~h}$, co-cultured with normal brain tissue homogenate (siNSCs+N group); and v) NSCs transfected with $\beta$-catenin siRNA for $24 \mathrm{~h}$, co-cultured with HIBD brain tissue homogenate (siNSCs+HIBD group).

Detection of NSC differentiation by immunofluorescence. The immunofluorescence staining was performed $48 \mathrm{~h}$ after transfection according to the methods of a previous study (17). NSCs were fixed in ReadiUse ${ }^{\mathrm{TM}} 4 \%$ formaldehyde fixation solution (AAT Bioquest, Sunnyvale, CA, USA) for 15-20 min at room temperature, and then permeabilized with $1 \%$ (vol/vol) Triton X-100 (Invitrogen; Thermo Fisher Scientific, Inc.) in phosphate-buffered saline (PBS; Hyclone; GE Healthcare Life Sciences) for $30 \mathrm{~min}$, and incubated in blocking buffer which contained 10\% goat serum (Biorbyt, Cambridge, UK) for $10 \mathrm{~min}$. The cells were incubated with primary antibodies overnight at $4{ }^{\circ} \mathrm{C}$ and secondary antibodies for $30 \mathrm{~min}$ at room temperature. The primary antibodies used were as follows: Mouse forkhead box O4 (O4) antibody (1:50; Abcam, 


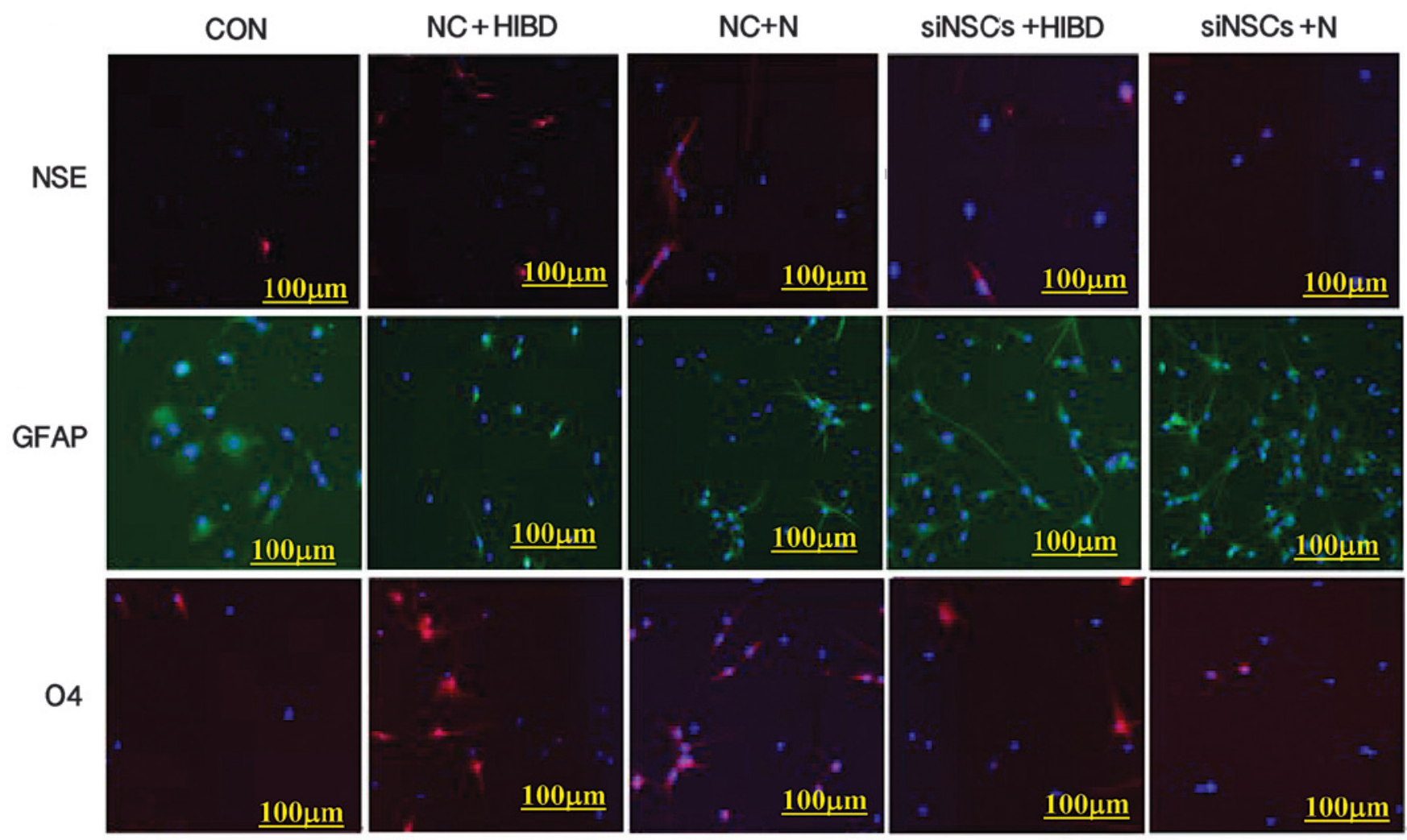

Figure 1. Expressions of NSE, O4 and GFAP in the experimental groups indicating NSC differentiation by fluorescence microscopy (x100). Immunofluorescence staining performed simultaneously on each group, red (CY3) represents the expression NSE or O4 in cytoplasm, green (FITC) represents the expression of GFAP in cytoplasm, blue (Hoechst 33258) represents the nucleus. NSC, neural stem cell; NSE, enolase 2; GFAP, glial fibrillary acidic protein; O4, oligodendrocyte cell surface antigen $\mathrm{O} 4$; $\mathrm{CON}$, blank control group; $\mathrm{NC}$, negative control plasmid-transfected cells; $\mathrm{N}$, normal brain tissue; HIBD, hypoxic-ischemic brain damage tissue; siNSC, $\beta$-catenin small interfering RNA-transfected cells.

Cambridge, MA, USA; cat. no. ab128908), rabbit enolase 2 (NSE) antibody (1:50; Abcam; cat. no. ab53025), and rabbit glial fibrillary acidic protein (GFAP) antibody (1:50; Abcam; cat. no. ab7260). The secondary antibodies were fluorescein isothiocyanate (FITC)-conjugated goat anti-rabbit IgG antibody (1:100; Wuhan Boster Biological Technology, Ltd., Wuhan, China; cat. no. SA1064) and CY3-conjugated goat anti-rabbit IgG antibody (1:100; Wuhan Boster Biological Technology, Ltd.; cat. no. SA1074). Following removal of the secondary antibodies, $50 \mu 1$ Hoechst $33258(10 \mu \mathrm{g} / \mathrm{ml}$; Wuhan Boster Biological Technology, Ltd.) was added and incubated in darkness at room temperature for $20 \mathrm{~min}$. Coverslips were mounted with $50 \mathrm{ml} / 1$ buffered glycerol (Fuzhou Maixin Biotechnology Development Co., Ltd.), and cells were imaged under a BX61 fluorescence microscope (Olympus Corporation). The experiment was performed 6 times and 6 non-overlapping fields of vision were captured. The differentiation percentages of NSCs to neurons or glial cells were then calculated according to the following formulae: (NSE positively stained cells/Hoechst 33258-stained cells) x 100; (GFAP positively stained cells/Hoechst 33258-stained cells) x 100; and (O4 positively stained cells/Hoechst 33258-stained cells) x 100 .

Nestin immunofluorescence assay. The neurospheres cloned from single cells were inoculated into each well of 24-well plates with pre-polylysine-coated coverslips, and $1 \mathrm{ml}$ serum-free medium was then added to each well. The 24-well plates were then cultured at $37^{\circ} \mathrm{C}$ in $5 \% \mathrm{CO}_{2}$ for $2 \mathrm{~h}$ to allow cell adhesion prior to the Nestin immunofluorescence assay. The culture medium was removed and $1 \mathrm{ml}$ of $0.01 \mathrm{~mol} / \mathrm{l} \mathrm{PBS}$ containing $4 \%$ paraformaldehyde ( $\mathrm{pH} 7.2$ ) was added for $15 \mathrm{~min}$ at room temperature to fix cells. The cells were washed three times with $0.01 \mathrm{~mol} / \mathrm{l} \mathrm{PBS}(\mathrm{pH} 7.2$ ), and then $200 \mu \mathrm{l}$ of $0.01 \mathrm{~mol} / 1$ PBS containing $10 \%$ goat serum ( $\mathrm{pH}$ 7.2) was added into each well, and the plates were gently shaken at room temperature for $30 \mathrm{~min}$. Following removal of the blocking solution, $200 \mu \mathrm{l}$ rabbit anti-Nestin polyclonal antibody (dilution, 1:150; Abcam; cat. no. ab92391) was added to each well, and incubated with gentle shaking at room temperature for $1 \mathrm{~h}$, followed by overnight incubation at $4^{\circ} \mathrm{C}$. Following washing three times with PBS, FITC-conjugated goat anti-rabbit secondary antibody (dilution, 1:100) was added to each well, and gently shaken for $2 \mathrm{~h}$ in darkness at room temperature. Following further washing three times with PBS, glycerol phosphate buffer was used to mount the slices. The neurospheres with positive Nestin immunofluorescence were then observed using a fluorescence microscope with the excitation wavelength of $495 \mathrm{~nm}$ and an absorption wavelength of $520 \mathrm{~nm}$.

mRNA expression of Ngnl and BMP4 in NSCs assessed by semiquantitative reverse transcription-polymerase chain reaction $(R T-P C R)$. NSCs from the 5 experimental groups were collected $48 \mathrm{~h}$ after transfection and total RNA was extracted with TRIzol (Invitrogen; Thermo Fisher Scientific, 
Inc.) according to the manufacturer's instructions. Reverse transcription was performed to obtain cDNA for the PCR reaction using PrimeScript ${ }^{\mathrm{TM}}$ RT kits (Takara Biotechnology Co., Ltd., Dalian, China) according to the manufacturer's instructions at $37^{\circ} \mathrm{C}$ for $15 \mathrm{~min}$, followed by $85^{\circ} \mathrm{C}$ for $5 \mathrm{sec}$. The reaction system ( $20 \mu \mathrm{l}$ for each sample) was as follows: $4 \mu 1$ 5X PrimeScript Buffer; $1 \mu 1$ PrimeScript RT Enzyme mix I; $1 \mu 150 \mu \mathrm{mol} / 1$ Oligo dT Primer; $1 \mu 1100 \mu \mathrm{mol} / 1 \mathrm{random}$ hexamers; and $13 \mu \mathrm{l}$ total RNA. The PCR system $(15 \mu \mathrm{l}$ for each sample) was as follows: $7.5 \mu 12 \mathrm{X}$ Premix Ex Taq; $0.25 \mu \mathrm{l}$ forward primer $(10 \mu \mathrm{mol} / 1) ; 0.25 \mu \mathrm{l}$ reverse $\operatorname{primer}(10 \mu \mathrm{mol} / \mathrm{L})$; $3 \mu \mathrm{l}$ cDNA $(5 \mathrm{ng} / \mu \mathrm{L})$; and $4 \mu \mathrm{l}$ distilled water. GAPDH was used as the reference gene. The following primers were used to amplify the indicated fragments: Ngn 1, F 5'-CGGCCA GCGATACAGAGTC-3' and R 3'-TACGGGATGAAGCAG GGTG-5', amplified fragment size 190 bp; BMP4, F 5'-AGA GCCAACACTGTGAGGA-3' and R 3'-TGTCCAGGCACC ATTTCT-5', amplified fragment size 245 bp; and GAPDH, F 5'-ACCACAGTCCATGCCATCAC-3' and R 5'-TCCACC ACCCTGTTGCTGTA-3', amplified fragment size 450 bp. The reaction cycling parameters were as follows on a CFX96 Touch $^{\mathrm{TM}}$ real-time PCR system (Bio-Rad Laboratories, Inc., Hercules, CA, USA): Initial step $95^{\circ} \mathrm{C}$ for $5 \mathrm{~min} ; 35$ cycles $94^{\circ} \mathrm{C}$ for $30 \mathrm{sec}, 8^{\circ} \mathrm{C}$ for $30 \mathrm{sec}, 72^{\circ} \mathrm{C}$ for $30 \mathrm{sec}$, and final step $72^{\circ} \mathrm{C}$ for $5 \mathrm{~min}$. The PCR products were then electrophoretically separated on a $5 \%$ agarose gel. The optical density ratios of Ngn1 and BMP4 were normalized to GAPDH in each group to reflect the relative optical density. Ethidium bromide (Sigma-Aldrich) was used to visualize the DNA ladder.

Detection of Ngnl and BMP4 protein expression levels in NSCs by western blot. Total protein was extracted from NSCs of the 5 groups $48 \mathrm{~h}$ after transfection using radioimmunoprecipitation assay lysis buffer (Santa Cruz Biotechnology, Inc., Dallas, TX, USA). Protein concentration was determined using the Coomassie brilliant blue method and protein concentration of the samples was adjusted to $50 \mu \mathrm{g} / \mu \mathrm{l}$. The protein samples were loaded onto $12 \%$ SDS-polyacrylamide gels for electrophoresis. The voltage used through the concentration gel was $60 \mathrm{~V}$, and $100 \mathrm{~V}$ for the separating gel. Following electrophoresis, the proteins were transferred to a nitrocellulose membrane. After washing three times for $15 \mathrm{~min}$ in PBS, the nitrocellulose membrane was then immersed into blocking solution of $1 \%$ bovine serum albumin (Fuzhou Maixin Biotechnology Development Co., Ltd.) at room temperature for $2 \mathrm{~h}$. Following blocking, the membranes were incubated with primary antibody overnight at $4{ }^{\circ} \mathrm{C}$, followed by washing with PBS. The horseradish peroxidase-labeled secondary antibody was added, followed by incubation at room temperature for $2 \mathrm{~h}$. Visualization was conducted using the enhanced chemiluminescence (ECL Plus Western Blotting Detection reagent; GE Healthcare Life Sciences, Little Chalfont, UK). The intensity of bands was calculated with Image J 1.46 analysis software (imagej.nih.gov/ij/). The primary antibodies used were as follows: Polyclonal mouse Ngn1 (1:500; Abcam; cat. no. ab66498); monoclonal mouse BMP4 (1:500; Abcam; cat. no. ab39973) and monoclonal mouse $\beta$-actin $(1: 100$; Abcam; cat. no. ab6276). The secondary antibody was horseradish peroxidase-conjugated sheep anti-mouse $\operatorname{IgG}(1: 5,000$; Abcam; cat. no. ab6808).
Table I. Comparison of the positive ratios of NSC-expressed neural markers between the different groups.

\begin{tabular}{lccc}
\hline Group & NSE & GFAP & O4 \\
\hline CON & $5.26 \pm 1.71$ & $52.25 \pm 2.27$ & $5.70 \pm 0.70$ \\
NC+N & $10.81 \pm 0.90^{\mathrm{a}}$ & $40.48 \pm 1.97^{\mathrm{a}}$ & $34.42 \pm 2.77^{\mathrm{a}}$ \\
NC+HIBD & $15.88 \pm 1.05^{\mathrm{a}, \mathrm{c}}$ & $38.83 \pm 1.63^{\mathrm{a}}$ & $35.62 \pm 3.91^{\mathrm{a}}$ \\
siNSCs+N & $1.48 \pm 0.53^{\mathrm{b}}$ & $82.77 \pm 2.43^{\mathrm{b}}$ & $13.25 \pm 1.08^{\mathrm{b}}$ \\
siNSCs+HIBD & $2.83 \pm 0.79^{\mathrm{b}, \mathrm{d}}$ & $83.20 \pm 4.48^{\mathrm{b}}$ & $18.30 \pm 1.89^{\mathrm{b}, \mathrm{d}}$ \\
\hline
\end{tabular}

Data presented as $\chi \pm \mathrm{s}$ ( $\%$ positively-stained cells). ${ }^{\mathrm{a}} \mathrm{P}<0.05$ and ${ }^{\mathrm{b}} \mathrm{P}<0.01$ vs. $\mathrm{CON}$ group; ${ }^{\mathrm{c}} \mathrm{P}<0.05$ vs. $\mathrm{NC}+\mathrm{N}$ group; ${ }^{\mathrm{d}} \mathrm{P}<0.05$ vs. siNSCs+N group. NSC, neural stem cell; NSE, enolase 2; GFAP, glial fibrillary acidic protein; O4, oligodendrocyte cell surface antigen $\mathrm{O} 4$; $\mathrm{CON}$, blank control group; $\mathrm{NC}$, negative control plasmid-transfected cells; N, normal brain tissue; HIBD, hypoxic-ischemic brain damage tissue; siNSC, $\beta$-catenin small interfering RNA-transfected cell.

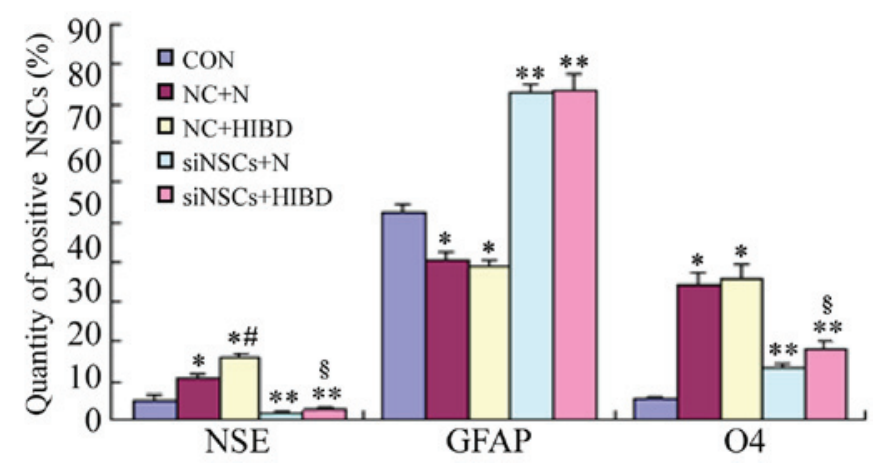

Figure 2. Positive ratios of NSCs-expressed neural markers in the different groups. The immunofluorescence staining was performed on the 5 groups simultaneously. The number of positive cells was measured $(\%)$, and expressed as $\chi \pm \mathrm{s}$. ${ }^{*} \mathrm{P}<0.05$ and ${ }^{* *} \mathrm{P}<0.01$ vs. $\mathrm{CON}$ group; ${ }^{\#} \mathrm{P}<0.05$ vs. $\mathrm{NC}+\mathrm{N}$ group; ${ }^{\circledR} \mathrm{P}<0.05$ vs. siNSCs+N group. NSC, neural stem cell; NSE, enolase 2 ; GFAP, glial fibrillary acidic protein; $\mathrm{O} 4$, oligodendrocyte cell surface antigen O4; CON, blank control group; NC, negative control plasmid-transfected cells; N, normal brain tissue; HIBD, hypoxic-ischemic brain damage tissue; siNSC, $\beta$-catenin small interfering RNA-transfected cell.

Statistical analysis. The experiments were repeated 5 times. The experimental data are expressed as $\chi \pm s$. SPSS statistical analysis software version 16.0 (SPSS, Inc., Chicago, IL, USA) was used for analysis of variance tests to compare the intergroup difference. $\mathrm{P}<0.05$ was considered to indicate a statistically significant difference.

\section{Results}

Culture and identification of NSCs. NSCs were observed using an inverted phase contrast microscope (CKX41; Olympus Corporation, Tokyo, Japan). The cultured cells appeared scattered with round-like shape, and small cell bodies, with good refraction. Following 3 days in culture, the cells grew gradually and formed cell balls composed of several cells. Following passage, single cells remained present in the medium, there were also small cell clumps, and some single cells undergoing cell division. Gradually, larger balls composed of more cells were formed. As observed by immunofluorescence staining, the 
Table II. Comparison of Ngn1 and BMP4 mRNA expression levels the different NSC groups.

\begin{tabular}{lll}
\hline Group & Ngn1 & BMP4 \\
\hline CON & $0.33 \pm 0.02$ & $0.44 \pm 0.01$ \\
NC+N & $0.37 \pm 0.03^{\mathrm{a}}$ & $0.32 \pm 0.02^{\mathrm{a}}$ \\
$\mathrm{NC}+\mathrm{HIBD}$ & $0.44 \pm 0.03^{\mathrm{a}, \mathrm{b}}$ & $0.17 \pm 0.03^{\mathrm{a}, \mathrm{b}}$ \\
siNSCs+N & $0.19 \pm 0.02^{\mathrm{a}-\mathrm{c}}$ & $0.72 \pm 0.04^{\mathrm{a}-\mathrm{c}}$ \\
siNSCs+HIBD & $0.17 \pm 0.03^{\mathrm{a}-\mathrm{c}}$ & $0.65 \pm 0.06^{\mathrm{a}-\mathrm{c}}$ \\
\hline
\end{tabular}

Data presented as relative optical density value $(\chi \pm s)$. ${ }^{a} \mathrm{P}<0.01$ vs. $\mathrm{CON}$ group; ${ }^{b} \mathrm{P}<0.01$ vs. $\mathrm{NC}+\mathrm{N}$ group; ${ }^{\mathrm{c}} \mathrm{P}<0.01$ vs. $\mathrm{NC}+\mathrm{HIBD}$ group. Ngn1, neurogenin 1; BMP4, bone morphogenetic protein 4 NSC, neural stem cell; CON, blank control group; NC, negative control plasmid-transfected cells; N, normal brain tissue; HIBD, hypoxic-ischemic brain damage tissue; siNSC, $\beta$-catenin small interfering RNA-transfected cell.
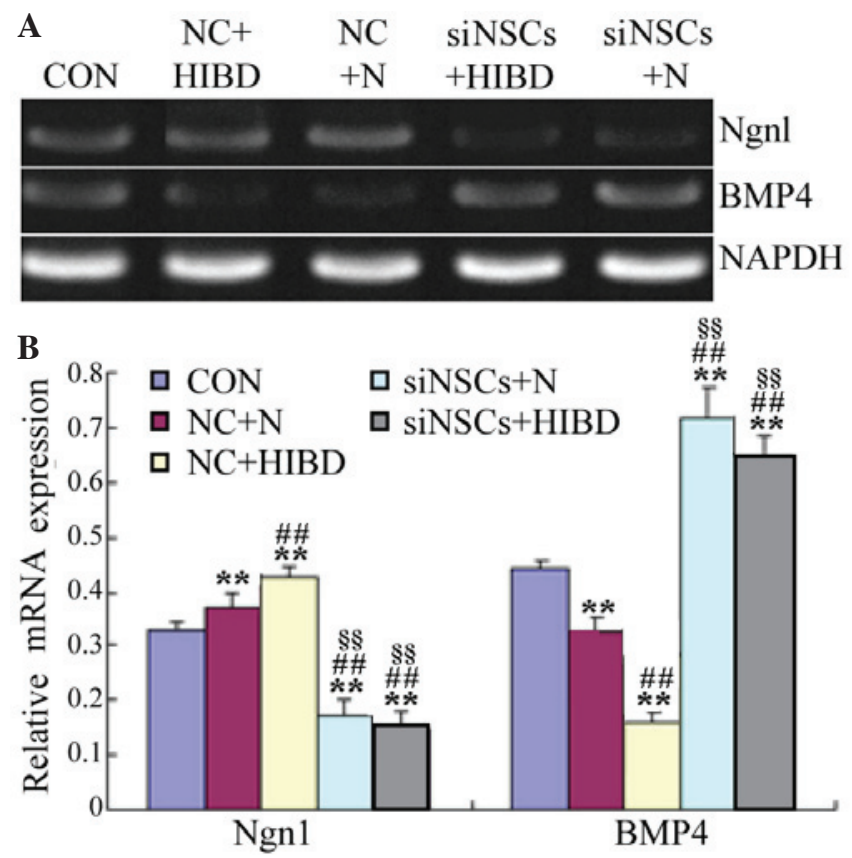

Figure 3. Expression levels of Ngn1 and BMP4 mRNA in NSCs following transfection with recombinant plasmid for $48 \mathrm{~h}$. (A) Detection of Ngn1 and BMP4 mRNA levels by reverse transcription-polymerase chain reaction. GAPDH was used as the internal control. (B) Semi-quantification of Ngn1/GAPDH and BMP4/GAPDH mRNA optical density ratios was conducted for each group. ${ }^{* *} \mathrm{P}<0.01$ vs. $\mathrm{CON}$ group; ${ }^{\# \#} \mathrm{P}<0.01$ vs. $\mathrm{NC}+\mathrm{N}$ group; ${ }^{\S} \mathrm{P}<0.01$ vs. NC+HIBD group. Ngn1, neurogenin 1; BMP4, bone morphogenetic protein 4; NSC, neural stem cell; CON, blank control group; NC, negative control plasmid-transfected cells; $\mathrm{N}$, normal brain tissue; HIBD, hypoxic-ischemic brain damage tissue; siNSC, $\beta$-catenin small interfering RNA-transfected cell.

primary and subcultured single cell balls were Nestin-positive. Fetal calf serum (10\%) was added to the culture medium for 2 days, subsequently, the NSC balls quickly adhered to the walls of the culture flasks and differentiated. Several processes were observed to protrude from the edge of cell balls. After 7 days, the cell balls disappeared, and the cells exhibited larger nuclei. The refraction was improved and the axons partially intertwined with each other forming a network.
Table III. Comparison of Ngn1 and BMP4 protein expression levels in the different NSC groups.

\begin{tabular}{lll}
\hline Group & \multicolumn{1}{c}{ Ngn1 } & BMP4 \\
\hline CON & $0.46 \pm 0.03$ & $0.59 \pm 0.03$ \\
NC+N & $0.58 \pm 0.02^{\mathrm{a}}$ & $0.43 \pm 0.03^{\mathrm{a}}$ \\
$\mathrm{NC}+\mathrm{HIBD}$ & $0.67 \pm 0.02^{\mathrm{a}, \mathrm{b}}$ & $0.41 \pm 0.06^{\mathrm{a}}$ \\
siNSCs+N & $0.39 \pm 0.04^{\mathrm{a}-\mathrm{c}}$ & $0.71 \pm 0.05^{\mathrm{a}-\mathrm{c}}$ \\
siNSCs+HIBD & $0.37 \pm 0.03^{\mathrm{a}-\mathrm{c}}$ & $0.77 \pm 0.01^{\mathrm{a}-\mathrm{c}}$ \\
\hline
\end{tabular}

Data presented as relative optical density value $(\chi \pm s)$. ${ }^{\mathrm{a}} \mathrm{P}<0.01$ vs. $\mathrm{CON}$ group; ${ }^{\mathrm{b}} \mathrm{P}<0.01$ vs. $\mathrm{NC}+\mathrm{N}$ group; ${ }^{\mathrm{c}} \mathrm{P}<0.01$ vs. $\mathrm{NC}+\mathrm{HIBD}$ group. NSC, neural stem cell; $\mathrm{CON}$, blank control group; NC, negative control plasmid-transfected cells; $N$, normal brain tissue; HIBD, hypoxic-ischemic brain damage tissue; siNSC, $\beta$-catenin small interfering RNA-transfected cell.
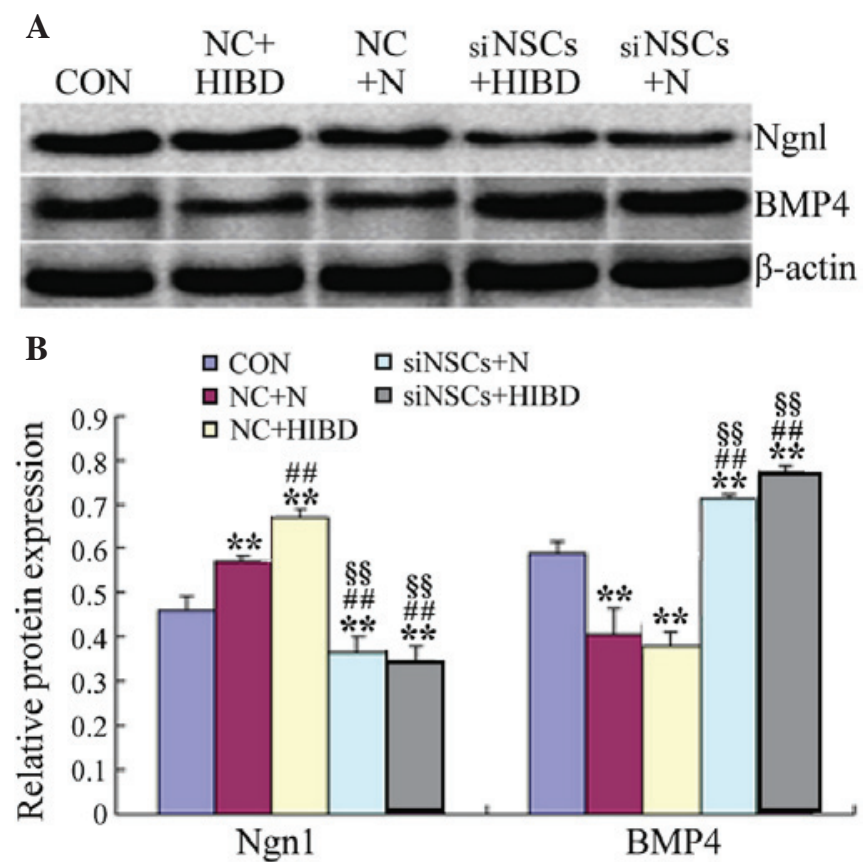

Figure 4. Expression levels of Ngn1 and BMP4 protein in NSCs following transfection with recombinant plasmid for $48 \mathrm{~h}$. (A) Detection of Ngn1 and BMP4 protein levels by western blot analysis. $\beta$-actin was the internal standard. (B) Ngn1/ $\beta$-actin and BMP4/ $\beta$-actin protein optical density ratios were analyzed in each group. ${ }^{* *} \mathrm{P}<0.01$ vs. $\mathrm{CON}$ group; ${ }^{\# \#} \mathrm{P}<0.01$ vs. $\mathrm{NC}+\mathrm{N}$ group; ${ }^{\S} \mathrm{P}<0.01$ vs. NC+HIBD group. Ngn1, neurogenin 1; BMP4, bone morphogenetic protein 4; NSC, neural stem cell; CON, blank control group; NC, negative control plasmid-transfected cells; $\mathrm{N}$, normal brain tissue; HIBD, hypoxic-ischemic brain damage tissue; siNSC, $\beta$-catenin small interfering RNA-transfected cell.

Differentiation of NSCs. Simultaneous staining for NSE (neuronal marker), GFAP (astrocyte marker) and O4 (oligodendrocyte precursor marker) was performed (Fig. 1), and the percentages of NSCs that differentiated into NSE-positive cells, GFAP-positive cells and O4-positive cells were counted using the fluorescence microscope (Table I, Fig. 2). Compared with the CON group, the differentiation into neurons and oligodendrocytes was increased in the $\mathrm{NC}+\mathrm{N}$ and the NC+HIBD groups (neuron differentiation, $\mathrm{P}=0.001$ and $\mathrm{P}=0.001$, 
respectively; oligodendrocyte differentiation, $\mathrm{P}=0.001$ and $\mathrm{P}=0.002$, respectively), while the differentiation into astrocytes was reduced (each $\mathrm{P}=0.001$ ). Compared with the $\mathrm{NC}+\mathrm{N}$ group, the NC+HIBD group exhibited increased differentiation into neurons $(\mathrm{P}=0.001)$, however, there was no statistically significant difference in the number of astrocytes or oligodendrocytes between the 2 groups. Compared with the CON group, the 2 siNSC groups transfected with $\beta$-catenin siRNA exhibited reduced differentiation into neurons $($ siNSC $+\mathrm{N}$ vs. $\mathrm{CON}$, $\mathrm{P}=0.001$; siNSC $+\mathrm{HIBD}$ vs. $\mathrm{CON}, \mathrm{P}=0.009)$ and increased differentiation into astrocytes (siNSC+N vs. $\mathrm{CON}, \mathrm{P}=0.001$; siNSC+HIBD vs. CON, $\mathrm{P}=0.001)$. Additionally, these siNSC groups exhibited increased differentiation into oligodendrocytes compared with the CON group $(\mathrm{P}=0.001)$, however, this was reduced compared with the $\mathrm{NC}$ group. Compared with the $\operatorname{siNSCs}+\mathrm{N}$ group, the siNSCs+HIBD group exhibited increased differentiation into neurons and oligodendrocytes (neuron, $\mathrm{P}=0.006$; oligodendrocyte, $\mathrm{P}=0.001$ ), however, these 2 groups showed no significant difference in the levels of differentiation into astrocytes (Figs. 1 and 2, Table I).

$\beta$-Catenin siRNA reduces Ngn1 and increases BMP4 mRNA expression levels in NSCs. Semiquantitative RT-PCR results demonstrated that, compared with the CON group, the expression levels of Ngn1 mRNA were significantly increased in the NC+HIBD group ( $\mathrm{P}=0.005$; Fig. 3 ), however, the BMP4 mRNA expression levels were significantly reduced $(\mathrm{P}=0.001)$. Compared with the $\mathrm{NC}+\mathrm{N}$ group, the expression levels of Ngn1 mRNA were significantly reduced in the NC+HIBD group ( $\mathrm{P}=0.004)$, however, BMP4 mRNA levels were significantly increased $(\mathrm{P}=0.001)$. Compared with the $\mathrm{CON}$ and $\mathrm{NC}$ groups, the Ngn1 mRNA levels were significantly decreased in the siNSC groups ( $\operatorname{siNSC}+\mathrm{N}$ vs. $\mathrm{CON}, \mathrm{P}=0.001$; siNSC $+\mathrm{N}$ vs. $\mathrm{NC}+\mathrm{N}, \mathrm{P}=0.001 ; \operatorname{siNSC}+\mathrm{N}$ vs. $\mathrm{NC}+\mathrm{HIBD}$, $\mathrm{P}=0.001$; siNSC+HIBD vs. $\mathrm{CON}, \mathrm{P}=0.002$; siNSC+HIBD vs. $\mathrm{NC}+\mathrm{N}, \mathrm{P}=0.001$; siNSC+HIBD vs. $\mathrm{NC}+\mathrm{HIBD}, \mathrm{P}=0.001$ ), whereas, the BMP4 mRNA levels were significantly increased (siNSC+N vs. $\mathrm{CON}, \mathrm{P}=0.001$; siNSC+N vs. $\mathrm{NC}+\mathrm{N}, \mathrm{P}=0.001$; siNSC+NC+HIBD, $\mathrm{P}=0.001 ;$ siNSC+HIBD vs. $\mathrm{CON}$, $\mathrm{P}=0.003$; siNSC+HIBD vs. $\mathrm{NC}+\mathrm{N}, \mathrm{P}=0.002$; siNSC $+\mathrm{HIBD}$ vs. $\mathrm{NC}+\mathrm{HIBD}, \mathrm{P}=0.001)$. No significant difference was observed in the mRNA levels of Ngn1 and BMP4 mRNA between the siNSCs+N and the siNSCs+HIBD groups (Fig. 3, Table II).

$\beta$-Catenin siRNA reduces Ngn1 and increases BMP4 protein levels in NSCs. As presented in Fig. 4 and Table III, western blot analysis demonstrated that, compared with the CON group, the levels of Ngn1 protein were significantly increased in the $\mathrm{NC}$ groups $(\mathrm{NC}+\mathrm{N}$ vs. $\mathrm{CON}, \mathrm{P}=0.027$; $\mathrm{NC}+\mathrm{HIBD}$ vs. $\mathrm{CON}$, $\mathrm{P}=0.001)$, however, BMP4 protein levels were significantly reduced $(\mathrm{NC}+\mathrm{N}$ vs. $\mathrm{CON}, \mathrm{P}=0.003$; $\mathrm{NC}+\mathrm{HIBD}$ vs. $\mathrm{CON}$, $\mathrm{P}=0.008)$. Compared with the $\mathrm{NC}+\mathrm{N}$ group, the expression levels of Ngn1 protein were significantly increased in the $\mathrm{NC}+\mathrm{HIBD}$ group $(\mathrm{P}=0.002)$. The protein expression levels of Ngn1 protein were decreased in the siNSC groups compared with the $\mathrm{CON}$ and $\mathrm{NC}$ groups (siNSC+N vs. $\mathrm{CON}, \mathrm{P}=0.048$; siNSC+N vs. $\mathrm{NC}+\mathrm{N}, \mathrm{P}=0.001$; $\operatorname{siNSC}+\mathrm{N}$ vs. $\mathrm{NC}+\mathrm{HIBD}$, $\mathrm{P}=0.001$; siNSC+HIBD vs. $\mathrm{CON}, \mathrm{P}=0.023$; siNSC+HIBD vs. $\mathrm{NC}+\mathrm{N}, \mathrm{P}=0.001$; siNSC+HIBD vs. NC+HIBD, $\mathrm{P}=0.001 ;$ Fig. 4 ), whilst the levels of BMP4 protein were significantly increased
(siNSC+N vs. $\mathrm{CON}, \mathrm{P}=0.023$; $\mathrm{siNSC}+\mathrm{N}$ vs. $\mathrm{NC}+\mathrm{N}, \mathrm{P}=0.001$; siNSC+N vs. $\mathrm{NC}+\mathrm{HIBD}, \mathrm{P}=0.002$; siNSC+HIBD vs. $\mathrm{CON}$, $\mathrm{P}=0.001$; siNSC+HIBD vs. $\mathrm{NC}+\mathrm{N}, \mathrm{P}=0.001$; siNSC+HIBD vs. NC+HIBD, $\mathrm{P}=0.001$; Fig. 4). No significant difference was observed between the levels of Ngn1 and BMP4 protein in the siNSCs+N and the siNSCs+HIBD groups (Fig. 4, Table III).

\section{Discussion}

Previous experiments by Zhang et al (15) have successfully isolated and cultured NSCs from the cortex tissues of newborn SD rats. They confirmed that the cells were NSCs, and that they exhibited continuous potential for proliferation and differentiation. RNA interference is used to inhibit the expression of specific genes, resulting in targeted gene silencing $(18,19)$. siRNAs are small non-coding RNA molecules of 21 to 25 nucleotides in length. They are widely used to reduce the expression of a gene to investigate its function. The siRNA vector used to target rat $\beta$-catenin in the present study has been previously demonstrated to specifically inhibit the expression of $\beta$-catenin $(15,20)$.

In order to further explore the repair mechanisms that occur following HIBD, the current study divided NSCs into 5 treatment groups. Immunocytochemical staining revealed that normal and HIBD brain tissue homogenate promoted NSCs to differentiate into neurons and oligodendrocytes, however, differentiation to astrocytes was suppressed. Notably, the promotion and suppression effects in HIBD brain tissue homogenates were greater than those in normal brain tissue homogenates. $\beta$-catenin siRNA inhibited the differentiation of NSCs to neurons, whereas, differentiation to astrocytes was promoted. These results suggested that the local microenvironment has an important impact on the differentiation of NSCs, and that when damaged by hypoxia/ischemia, changes to the brain microenvironments may stimulate proliferation and differentiation of NSCs, thus, initiating autogenous healing processes. Additionally, the results of the current study suggest that $\beta$-catenin is important in facilitating the differentiation of NSCs to neurons.

The differentiation of NSCs is dependent on the microenvironment and the regulation of various genes (21-23). Previous studies have demonstrated that the development of NSCs is closely associated with the Wnt, BMP and sonic hedgehog signaling systems. They have investigated how the Wnt/ $\beta$-catenin signaling pathway regulates the development and differentiation of NDCs $(24,25)$. Following activation, $\beta$-catenin is translocated into the nucleus, where the $\beta$-catenin/T-cell factor complex directly regulates the transcription of Ngnl, thus, regulating the differentiation of NSCs $(26,27)$. BMP4 is an important regulator of neural development. During the development of the nervous system, there is 'crosstalk' between the BMP and Wnt signaling pathways (28-30). Therefore, the current study measured the expression levels of Ngn1 and BMP4 in NSCs exposed to HIBD brain tissue homogenate by semiquantitative RT-PCR and western blotting. The results of the present study suggested that the expression levels of Ngn1 protein and mRNA were increased with the increased differentiation of NSCs into neurons, and that the expression levels of BMP4 protein and mRNA were reduced with the reduced differentiation of NSCs into astrocytes. When $\beta$-catenin expression was inhibited by siRNA, the expression 
of Ngn1 protein and mRNA were reduced, and the differentiation of NSCs into neurons was decreased. Additionally, the expression level of BMP4 protein and mRNA was increased by $\beta$-catenin siRNA, and differentiation of NSCs into astrocytes was also increased. The results of the present study further illustrated that $\beta$-catenin siRNA inhibited the differentiation of NSCs to neurons and promoted the differentiation into astrocytes. In HIBD, the damaged brain tissues repair themselves, which may be associated with the fact that $\beta$-catenin promotes the differentiation of NSCs to neurons, and this mechanism may be mediated by $\beta$-catenin-induced upregulation of Ngn1. BMP4 and Ngn1 are important in the differentiation of NSCs in HIBD, and BMP4 may inhibit the expression of Ngn1. The importance of Ngn1 in promoting the differentiation of NSCs suggests that it may be an important contributor for the repair of brain function following HIBD.

In conclusion, the damaged brain tissues in HIBD may promote NSCs to differentiate into neurons for self-repair processes. $\beta$-catenin, BMP4 and Ngn1 may be important in the coordination of NSC proliferation and differentiation following HIBD. The present study demonstrated that in HIBD, Ngn1 can promote the differentiation of endogenous neural stem cells to neurons, thus, repairing brain damage, and that this process is via the Wnt/ $\beta$-catenin signaling pathway. The current study also provides a foundation for future studies using genetically modified neural stem cells for the treatment of HIBD.

\section{Acknowledgements}

The current study was funded by the National Natural Science Foundation of China (no. 81460195).

\section{References}

1. Nanavati T, Seemaladinne N, Regier M, Yossuck P and Pergami P: Can we predict functional outcome in neonates with hypoxic ischemic encephalopathy by the combination of neuroimaging and electroencephalography? Pediatr Neonatol 56: 307-316, 2015.

2. Buonocore G, Perrone S, Longini M, Paffetti P, Vezzosi P, Gatti MG and Bracci R: Non protein bound iron as early predictive marker of neonatal brain damage. Brain 126 1224-1230, 2013.

3. Cai Q, Xue XD and Fu JH: Research status and progress of neonatal hypoxic ischemic encephalopathy. Zhong Guo Shi Yong Er Ke Za Zhi 24: 968-971, 2009 (In Chinese).

4. Vanucci RC and Perlman JM: Interventions for perinatal hypoxic-ischemic encephalopathy. Pediatrics 100: 1004-1014, 1997.

5. Sun D: Endogenous neurogenic cell response in the mature mammalian brain following traumatic injury. Exp Neurol 275: 405-410, 2016.

6. Sun D: The potential of endogenous neurogenesis for brain repair and regeneration following traumatic brain injury. Neural Regen Res 9: 688-692, 2014.

7. Edelmann K, Glashauser L, Sprungala S, Hesl B, Fritschle M, Ninkovic J, Godinho L and Chapouton P: Increased radial glia quiescence, decreased reactivation upon injury and unaltered neuroblast behavior underlie decreased neurogenesis in the aging zebrafish telencephalon. J Comp Neurol 521: 3099-3115, 2013.

8. Oliva CA and Inestrosa NC: A novel function for Wnt signaling modulating neuronal firing activity and the temporal structure of spontaneous oscillation in the entorhinal-hippocampal circuit. Exp Neurol 269: 43-55, 2015.

9. Oliva CA, Vargas JY and Inestrosa NC: Wnts in adult brain: From synaptic plasticity to cognitive deficiencies. Front Cell Neurosci 7: 224, 2013.

10. Inestrosa NC and Varela-Nallar L: Wnt signaling in the nervous system and in Alzheimer's disease. J Mol Cell Biol 6: 64-74, 2014
11. Liu W, Zhou H, Liu L, Zhao C, Deng Y, Chen L, Wu L, Mandrycky N, McNabb CT, Peng Y, et al: Disruption of neurogenesis and cortical development in transgenic mice misexpressing Olig2, a gene in the Down syndrome critical region. Neurobiol Dis 77: 106-116, 2015.

12. Liu F, Xuan A, Chen Y, Zhang J, Xu L, Yan Q and Long D: Combined effect of nerve growth factor and brain derived neurotrophic factor on neuronal differentiation of neural stem cells and the potential molecular mechanisms. Mol Med Rep 10: 173917-173945, 2014.

13. Lei ZN, Liu F, Zhang LM, Huang YL and Sun FY: Bcl-2 increases stroke-induced striatal neurogenesis in adult brains by inhibiting BMP-4 function via activation of $\beta$-catenin signaling. Neurochem Int 61: 34-42, 2012.

14. Chuang CY, Lin KI, Hsiao M, Stone L, Chen HF, Huang YH, Lin SP, Ho HN and Kuo HC: Meiotic competent human germ cell-like cells derived from human embryonic stem cells induced by BMP4/WNT3A signaling and OCT4/EpCAM (epithelial cell adhesion molecule) selection. J Biol Chem 287: 14389-14401, 2012.

15. Zhang XY, Yang YJ, Xu PR, Zheng XR, Wang QH, Chen CF and Yao $\mathrm{Y}$ : The role of $\beta$-catenin signaling pathway on proliferation of rats neural stem cells after hyperbaric oxygen therapy in vitro. Cell Mol Neurobiol 31: 101-109, 2011.

16. Rice JE III, Vannucci RC and Brierley JB: The influence of immaturity on hypoxic-ischemic brain damage in the rat. Ann Neurol 9: 131-141, 1981.

17. Chen CF, Yang YJ, Wang QH, Yao Y and Li M: Effect of hyperbaric oxygen administered at different pressures and diffrernt exposure time on differentiation of neural stem cells in vitro. Zhongguo Dang Dai Er Ke Za Zhi 12: 368-372, 2010 (In Chinese).

18. Shyam R, Ren Y, Lee J, Braunstein KE, Mao HQ and Wong PC: Intraventricular delivery of siRNA nanoparticles to the central nervous system. Mol Ther Nucleic Acids 4: e242, 2015.

19. Li TS, Yawata T and Honke K: Efficient siRNA delivery and tumor accumulation mediated by ionically cross-linked folic acid-poly(ethylene glycol)-chitosan oligosaccharide lactate nanoparticles: For the potential targeted ovarian cancer gene therapy. Eur J Pharm Sci 52: 48-61, 2014.

20. Zhang XY, Yang YJ, Chen CF, Yao Y and Wang QH: Construction and screening of eukaryotic expression plasmids containing shRNA targeting $\beta$-catenin gene. J Med Mol Biol 7: 136-142, 2010.

21. Gigek CO, Chen ES, Ota VK, Maussion G, Peng H, Vaillancourt K, Diallo AB, Lopez JP, Crapper L, Vasuta C, et al: A molecular model for neurodevelopmental disorders. Transl Psychiatry 5: e565, 2015.

22. Chen ES, Gigek CO, Rosenfeld JA, Diallo AB, Maussion G, Chen GG, Vaillancourt K, Lopez JP, Crapper L, Poujol R, et al: Molecular convergence of neurodevelopmental disorders. Am J Hum Genet 95: 490-508, 2014.

23. Rak K, Völker J, Jürgens L, Völker C, Frenz S, Scherzad A Schendzielorz P, Jablonka S, Mlynski R, Radeloff A and Hagen R: Cochlear nucleus whole mount explants promote the differentiation of neuronal stem cells from the cochlear nucleus in co-culture experiments. Brain Res 1616: 58-70, 2015.

24. Schafer ST, Han J, Pena M, von Bohlen Und Halbach O, Peters J and Gage FH: The Wnt adaptor protein ATP6AP2 regulates multiple stages of adult hippocampal neurogenesis. J Neurosci 35: 4983-4998, 2015

25. Wang L, Liu Y, Li S, Long ZY and Wu YM: Wnt signaling pathway participates in valproic acid-induced neuronal differentiation of neural stem cells. Int J Clin Exp Pathol 8: 578-585, 2015.

26. Ma YX, Wu ZQ, Feng YJ, Xiao ZC, Qin XL and Ma QH: G protein coupled receptor 50 promotes self-renewal and neuronal differentiation of embryonic neural progenitor cells through regulation of notch and wnt $/ \beta$-catenin signalings. Biochem Biophys Res Commun 458: 836-842, 2015.

27. Yuan L and Hassan BA: Neurogenins in brain development and disease: An overview. Arch Biochem Biophys 558: 10-13, 2014.

28. Imayoshi I and Kageyama R: bHLH factors in self-renewal, multipotency, and fate choice of neural progenitor cells. Neuron 82: 9-23, 2014

29. Zhang Z, Shi Y, Zhao S, Li J, Li C and Mao B: Xenopus Nkx6.3 is a neural plate border specifier required for neural crest development. PLoS One 9: e115165, 2014.

30. An SM, Ding Q, Zhang J, Xie J and Li L: Targeting stem cell signaling pathways for drug discovery: Advances in the Notch and Wnt pathways. Sci China Life Sci 57: 575-580, 2014. 